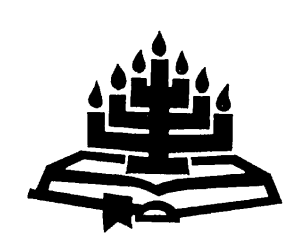

\title{
Towards a revitalisation of Calvinistic eschatology 1
}

\author{
Jan Hoek \\ Theological Academy of the Reformed League Johannes Calvijn \\ (Theologische Hogeschool van de Gereformeerde Bond \\ Johannes Calvijn) \\ EDE \\ The Netherlands \\ E mail: jhoek@che.nl
}

\begin{abstract}
Towards a revitalisation of Calvinistic eschatology

The theology of John Calvin has a structurally Christocentric and eschatological character. In Calvin's theology eschatology does not deal with probabilities and speculations about the future, but with the reliable promises of God in Christ. The Kingdom is already a realised kingdom in the cross-bearing Church on earth. According to Calvin the Millenarians deprive Christ of His honour by assigning to Him a temporal kingdom. Calvin rejects the idea that the Old Testament prophecies of salvation and blessings will only be fulfilled to the people of Israel in future world-history.
\end{abstract}

According to Millenarianism, Old Testament prophecy - concerning the messianic kingdom - should be interpreted as referring to the physical kingdom of Israel on earth. The main route of God through history is His way with Israel. This way of thinking, however, overemphasizes the theologia gloriae. Nevertheless, in these millenarian views the insistence on the unique place of Israel in God's plan of salvation has to be welcomed. Calvinists have a tradition (Puritans, Nadere Reformatie) of openness to a preliminary fulfilment of God's promises in future history. Calvinists do not need to change their Christocentric paradigm when they accept the hope upon the future conversion of the Jews. A revitalisation of Puritan insights in this regard will be refreshing for contemporary Calvinism.

1 Elaborated version of a lecture held at the Hugenote Kollege, Wellington, RSA, 19.02.02, with thanks to my colleagues at the Christian Academy for Higher Education, Ede, the Netherlands: drs. Theo van Campen, dr. Johan Hegeman and dr. Mart-Jan Paul. 
Opsomming

Naar een revitalisering van de calvinistische eschatologie

De theologie van Johannes Calvijn kent een christocentrische en eschatologische structuur. Het koninkrijk is reeds realiteit geworden in de kruisdragende Kerk op aarde. Volgens Calvijn beroven de chiliasten Christus van zijn eer door Hem slechts een tijdelijk koninkrijk toe te kennen. Hij verwerpt de opvatting dat de oudtestamentische beloften van heil en zegeningen nog een vervulling zullen krijgen in de toekomstige geschiedenis van het volk van Israël.

De chiliasten verwachten een fysiek toekomstig rijk voor het volk Israël op aarde. De hoofdroute die God gaat door de geschiedenis is zijn weg met Israël. Op deze wijze wordt de theologia gloriae te sterk benadrukt. In deze chiliastische opvattingen is echter de affiniteit met het Joodse volk en de nadruk op de unieke plaats van dit verkoren volk in Gods heilsplan te verwelkomen. Calvinisten kennen een traditie van openheid voor een voorlopige vervulling van Gods beloften in de geschiedenis die voor de jongste dag nog voor ons ligt. Een revitalisering van de inzichten van de Puriteinen en van de mannen van de Nadere Reformatie op dit punt zal verfrissend werken voor het hedendaagse calvinisme.

Dutch orthodox Calvinists increasingly interact with Evangelicals who have various chiliastic opinions: premillennialists, postmillennialists or dispensationalists. On the one hand, we see much doctrinal unity between Calvinists and these Evangelicals, for instance, their mutual regard for the authority of Scripture, the person and the work of Christ and the need for personal faith and regeneration. On the other hand, we discover crucial differences. One area in which there has always been much disagreement between classic orthodox Calvinists and representatives of the radical Reformation (Anabaptist Radicals) is that of eschatology, the doctrine of the last things, the great end time events (Balke,1973:308-313). Yet, the growing contact between these two groups also achieves the positive effect of a revitalisation of the Christian hope for the future. A less positive effect, though, is a growing confusion concerning several eschatological conceptions. This prompts us to ask the question of how Calvinists and millennialists, mostly Evangelicals with a more Methodist or Pentecostal background, can learn from one another for the mutual aim of enriching their visions of our future with Christ? In this article, I will concentrate on the possibility of a revitalisation of Calvinistic eschatology by this encounter.

\section{Calvinistic eschatology}

In the first place, I will summarize some important aspects of Calvinistic eschatology. To start with, we must understand that the theology of John 
Calvin has a structurally Christocentric and eschatological character. His approach to eschatology has rightfully been characterized as "a Christocentric paradigm" (Möller, 1998:75). This paradigm implies two important things:

- Our approach and interpretation of eschatology has to start with Christ's own sayings about His second coming and the events related to it. The highly debated 20th chapter of Revelation and all the other biblical prophecies and visions about the end of times have to be interpreted in the light of the words of Christ Himself.

- The person of Christ is central and crucial in Christian eschatology. Therefore, we need a clear concept of His place and role in human history. He is the One around whom everything revolves. Our attention should never be diverted from Christ to any events or possible developments related to the last days as such.

Eschatology does not deal with probabilities and speculations about the future ${ }^{2}$, but with the reliable promises of God that will be realised from, through and unto Christ. This Christocentric paradigm surely means that Calvinistic theology, and so Calvinistic eschatology (see Quistorp, 1941; Torrance, 1956; Holwerda, 1976:137; Van Campen,1988:105-136), can be characterized as a theologia crucis, a theology of the cross. Reading what Calvin has said about the last things in his Institutes of Christian Religion, we see that he continually stresses the meditatio futurae vitae, the meditation of the future life. That is the contemplation of the eternal life in heaven in the communion with Christ and through Him with the triune God. For Calvin, the centre and core of the Christian expectation of the future lies in the visio Dei beatifica, the glorious vision of God, and the frui Deo, the enjoying of God. In this earthly life we are called to the disciplina crucis, the school or training of the cross. The life of the believers has to be a life of cross-bearing and self-denial in the footsteps of Christ (see De Reuver, 1978:116-142; Bremmer, 1943:74 e.v.). Calvin goes as far as to speak of the contemptio huius praesentis vitae, the contempt or despising of this present life on earth. Within this framework of the theologia crucis there is no place for what the Confessio Helvetica Posterior has called judaica somnia, "Jewish dreams", about all kinds of positive and glorious events and developments in future on earth (Müller, 1903:1853; Meyer, 1966:402; Tukker, 1975). In the same way Calvin

2 "Calvijn heeft in zijn eschatologie alle speculatie afgewezen ... Hij heeft de troost van de eschatologie weer doen uitschitteren in de verwachting van de komende Christus, die de gelovigen uit hun tegenwoordige lijden verlossen zal” (Bremmer, 1943:95).

3 Art. XI: "Damnamus praeterea ludaica somnia, quod ante iudicii diem aureum in terris sit futurum seculum, et pii regna mundi occupaturi, oppressis suis hostibus impiis. Nam 
regards people who advocate the expectation of an earthly kingdom of peace in future as childish. 4

In this kairos the Church will always be an ecclesia militans, a struggling Church, and will never be an ecclesia triumphans, a church that is triumphing and has already won the battle. The Christian hope is fully and in a radical way concentrated upon the eternal beatitude in heaven.

We would not be warranted though in stating that Calvin's eschatology has a pure individualistic character. He is not advocating a Jenseitschristentum or otherworldliness (against Schulze, 19015; see also Brunner, 1925:1486), faith is not only directed to eternity. On the contrary, Calvin is grateful for the many undeserved blessings we receive in this temporal life from the hands of our heavenly Father. And he also stresses the vocatio, the vocation we have to fulfil on our statio, our place of service and expectation on earth. ${ }^{7}$ Calvin combines the individualistic with the collective or cosmological aspects into a biblically balanced approach (Van den Berg, 1996). 8 This balance is reached by the prominence in Calvin's thinking of the central and crucial place of the promissio Dei, the promise of God. Relying on the promises of God, Calvin looks forward to the completion and glorification of the church, the resurrection of the body and the renewal of heaven and earth, and not

evangelica veritas Matth. 24 et 25, Luc. item 18 et Apostolica doctrina 2 Thess. 2 et in 2 ad Tim. 3 et 4 capite, longe aliud perhibere inveniuntur."; Edwardine Articles (1552)XLI: "Qui Millenariorum fabulam revocare conantur, sacris literis adversantur, et in ludaica deliramenta sese praecipitant" (Müller, 1903:521).

Inst. III,25,5, OS IV, 439,440: "sed paulo post sequuti sunt Chiliastae, qui mille annis finierunt Christi regnum. Ac eorum quidem commentum puerilius est quam ut refutatione vel indigeat, vel dignum sit. Nec illis suffragatur Apocalypsis, ex qua errori suo colorem induxisse certum est: quando in millenario numero [Apoc.20.a.4] non agitur de aeterna Ecclesiae beatitudine, sed tantum de variis agitationibus quae Ecclesiam adhuc in terris laborantem manebant."

5 "Calvin hat das mönchische Lebensideal nicht im Prinzip überwunden" (Schulze, 1901:18).

"Für den Glauben als fides qua creditur ist bezeichnend ein Zug zur Jenseitigkeit, zur Ewigkeit, zum Zukünftigen, zum jetzt Verborgenen, einst Offenbaren" (Brunner, 1925:147). Cf. Inst. III,2,42: "Hic fidem spei tolerantia suffultam, in aeternitatis contemplatione defixam retineri oportet, quo mille annos instar diei unius reputet" (OS IV,53).

7 "Gerade die seria divinae bonitatis meditatio treibt uns wie nichts anderes zum Gehorsam gegen Gott. Dass wir Gott geweiht sind (consecrati), setzt uns in Bewegung und spornt uns zu guten Werken an" (Ellwein, 1953:98).

8 Holwerda, 1976:137: "His dynamic eschatological vision is articulated more clearly and forcefully in the appropriate Biblical commentaries than it is in the Institutes". 
just only for the salvation and the beatitude of the soul. Calvin aknowledges an eager expectation of the momentous event of the second coming of the Lord Jesus in His glory (Grier, 1945). For him, eschatology becomes essentially Christology. The knowledge of Christ by faith, the mystical union with Him, is the source of our hope for His final revelation in glory. ${ }^{9}$ In a certain sense and up to a point, nothing new has to occur anymore. The reason is that the salvation has fully been given in the person and the work of Christ to the believer and thereby to the Church. The Kingdom is principally a realised Kingdom in the Church on earth (Van der Kooi, 1992:252).

Calvin thus has little to do with the doctrine of the Millennium and even speaks of a "horrendum dictu delirium"10. In his opinion the Millenialists deprive Christ of His honour by assigning to Him a temporal kingdom. Further, Calvin abstains from any concrete filling in of the mode of the eternal beatitude, for, he reasons, the prophets clearly used corporal images for describing spiritual realities. In fact, believers have no words to represent the spiritual happiness that will once be revealed in the heavenly realm.11 The soberness of Calvin in his speaking about the future is deeply rooted in his persuasion that it is impossible for us to grasp what this salvation is all about (De Greef, 1984:135). Yet, by grace, it may be clear to us what is the most important aspect of eternal life: the core of the beatitude is the enjoying of God (frui Deo). Calvin stresses the richness of the hope that we may be with Christ in all eternity.

We may conclude that Calvin's eschatology has a spiritualising and individualising tendency (Balke, 1973:313; Velema, 1974:34-3512). However, this tendency is counterbalanced by his obedience to the Scriptural testimony of the resurrection of the body and the renewal of the cosmos

$9 \quad$ M.A. van den Berg (1996:270): "De wederkomst is de uiteindelijke ratificatie van Zijn heilswerk in de volle zin, allereerst in kosmische volheid". See Calvin's Institutes II,16,17 where he deals with the appearance of Christ in the unspeakable majesty of his glorious kingdom.

10 CO52,167 (1 Thess.4:17): "Semel ad Christum aggregatis promittit aeternam cum eo vitam; quibus verbis abunde Originis et Chiliastorum deliria refutentur...Christo autem mille annos tribuere ut postea regnare desinat, plus quam horrendum dictu est. Atqui in hanc absurditatem cadunt qui mille annis terminant fidelium vitam, quia vivere eos cum Christo oportet quamdiu erit Christus ipse."

11 OS IV,453: "Quamobrem Prophetae, quia spiritualem illam beatitudinem in seipsa nullis verbis exprimere poterant, sub rebus corporeis eam fere delinearunt."

12 Regarding Inst. III,7-9 Velema (1974:35) states: “... er zit in Calvijns uitdrukkingen iets hards en iets negatiefs, dat ons over de grens van het bijbelse spreken schijnt te gaan. Deze verachting voedt een vreemdelingschap, die zich terugtrekt". 
(Van der Linde, 1976:59-73). Perhaps in a somewhat reluctant and hesitating way, Calvin speaks about the significance of the "orbis reparatio". But, Calvin warns us, whom by his curiosity wants to know what the new heaven and earth will be like, is making himself guilty of posing inane and even harmful questions. ${ }^{13}$ Such speculations distract us from battling to reach our goal, as real pilgrims do.14 Calvin then rejects the idea that the Old Testament prophecies of future salvation and blessings will be fulfilled to the people of Israel in future worldhistory. 15 The fulfilment of the prophecies has already been given in Christ. The future will bring the complete unveiling of the salvation, which is already present in Christ and is already experienced by faith. Speculations about the concrete fulfilment of the prophecies in future history harm the reliability of the Word of God (M.A. van den Berg, 1996:277; De Boer, 1997:39: "Calvin's theology is anti-speculative, contra curiositatem"). The promises which are contained in the Scriptures regarding the dominion of Christ may not be limited to a certain time, but are valid during the whole period from the first until the second coming of Christ on earth.16 Therefore, there is in history but one relevant item between adventus and parousia, the first and the second coming of the Lord: the great fight between the Kingdom of Christ and that of the Antichrist. No speculation may divert us from this battle in which we will persevere by the steadfastness of our hope. The time in which we live is not a time of waiting until the so important "last things" will have begun to occur, but it is already the time of the decisive "last days"! What the prophets had testified about the future, remained veiled for a long time under the dense haze of oppression. Nevertheless, once it will be revealed on the day of the Lord. We can endure the oppression

13 Inst. III,25,10: "unde subinde et frivolae et noxiae quaestiones scaturiunt; frivolas voco, ex quibus nulla potest elici utilitas.", OS, IV,453. "Inquiunt multi, qualis olim futura sit beatitudo, quum in caelum recepti fuerint: quomodo autem illuc saltem accedant, nulla illis cura est”, CO 48,10 (Acts 1:8).

14 "Inst.III,25,11: Nam pauci ex ingenti multitudine qua in caelos eundum sit curant:omnes autem quid illic agatur scire ante tempus appetunt. Omnes fere ad obeundum certamina pigri et lenti, triumphos imaginarios sibi iam depingunt" (OS IV,455).

15 Calvin even lays a connection between the pride of the Jews and their longing for an earthly kingdom, Jes. 53:1-3, CO, 35, 616: “... a cause des luifs qui tousiours ont attendu un Royaume terrien; ç'a este une nation plene d'avarice et d'orgueil, tellement qu'ils ont pensé que Dieu ne se pouvoit monstrer pitoyable envers eux, sinon en leur amassant toutes les richesses du monde, et faisant qu'ils vesquissent en delices et en pompes. Voyla quel redempteur ils ont esperé."

16 These promises are valuable "ab initio usque ad finem", as Calvin frequently says. 
since we here and now already are partakers of the heavenly Kingdom by faith (see Scholl, 1968:58-60).17

Calvin takes an ambivalent position towards the Jewish people. Van Campen (1988:114-119) discerns two tendencies: a negative line and a positive line.

Positive: Jews and Christians have much in common: the covenant that God once has given to Abraham and his seed is one and the same for Christian believers.18 In both the Old and New Testament the same promises are at stake. 19 Christ is the foundation of both covenants. ${ }^{20}$ The difference between "old" and "new" lies only in the administratio, not in the substantia of the covenant.21 Thus God's covenant with Israel is no matter of the past alone, but has actual validity and relevancy.22 The Jews are like the firstborns in the family of God.23 The covenant of God with Abraham and his seed can in no way become invalid. One may not dare loosening the Jews from Christ and excluding them from the beneficences of grace. 24

17 "Das Gewicht der reformatorischen Eschatologie liegt in der Gegenwartsbedeutung des Gottesreiches ... Das regnum Christi oder Gottes ist nicht einfach ein letztes Kapitel seiner Dogmatik, sondern eine gegenwartig wirksame Realität." (59)

Inst. IV,16,6: "Foedus commune est, communis eius confirmandi causa" (OS V, 310).

19 Inst. II,10,8: "vitae spiritualis promissio".(OS III,409)

20 Inst. II,9,3;11,1: "Hac ratione nihil impedient quominus eadem maneant veteris ac novi Testamenti promissiones, atque idem ipsarum promissionum fundamentum, Christus" (OS III,400, 401; 423).

21 Inst. II,10,2: "Patrum omnium foedus adeo substantia et re ipsa nihil a nostro differt, ut unum prorsus atque idem sit, administratio tamen variat" (OS III,404).

22 Inst. IV,2,11: "Cum illis foedus suum semel pepigerat Deus; id sua magis ipsius firmitate subnixum contra eorum impietatem eluctando persistebat, quam ab illis conservabatur. Quae itaque certitudo est ac constantia divinae bonitatis, residebat illic foedus Domini: nec obliterari « illorum perfidia poterat eius fides ... (OS V,41).

23 Inst. IV,16,14: "quia tamen altera ex parte cernebat foedus quod semel cum Abrahae posteritate initum fuerat a Deo, irritum nullo modo fieri posse ... carnalem Abrahae cognitationem non esse sua dignitate spoliandam disserit: cuius beneficio ludaeos docet primos ac nativos esse Evangelii haeredes, nisi quatenus sua ingratitudine, ceu indigni, abdicati fuerunt: sic tamen, ut non penitus ab eorum gente caelestis benedictio demigrarit." OS V,317; Comm. Acts 20:21, CO 48,462: "... ludaeis tamen statuit priori loco."

24 Inst. II,10,4: "Quis igitur expertes Christi ludaeos facere ausit, quibuscum audimus fuisse percussum Evangelii foedus, cuius unicum fundamentum Christus est? Quis alienos reddere a gratuitae salutis beneficio, quibus administratam fuisse audimus iustitae fidei doctrinam?" OS III,405,406; cf. H. Krüger (1985:13) "Die Juden als 
Negative: At the other hand, Calvin states that the Church has replaced Israel and that all the promises of the Old Testament have been transferred to the Christian Church.25 The Jews are disinherited and they are lost 26 without Christ.27

This negative approach is not a last word28: there is always hope for the conversion of individual Jews and Calvin states that Israel has, due to the promise of God, the oldest rights and the first place among the peoples of the world29 (see Brienen, 1983:111-115; Spijkerboer, 1982: 80-86; Visser, 1963; Jansen, 1981:154-16130). There will always be a faithful rest in the midst of the reprobated Jewish people. 31 While the

Teilhaber des Evangeliums praktizieren die Gerechtigkeit aus dem Glauben - ich wüsste im Augenblick keine Aussage eines der Reformatoren, die so offen wäre gegenüber dem jüdischen Glauben, so 'tolerant' im ursprünglichen Sinne von 'tolerare' als 'tragen'."

25 Comm. Joh. 1:12 "Perinde est enim ac si ius adoptionis ad extraneos transferret" CO47,10; Zimmerli, 1932:28-31: "ubi vero surrexerit in gloriam suam coelestis Jerusalem et verus Salomon Christus, rex pacis, sublimis sederit in tribunali, regnabunt cum suo rege veri Israelitae"; Comm. Luc. 1:33 "Deus enim nova et admirabili adoptione gentes inseruit in familiam lacob, quae primus extraneae fuerant ..." CO $45,28$.

26 CO 46,178 (Sermon on Luc. 1:69): "Mais ils ont esté banniz et desheritez de la promesse qui leur estoit donneé, et s' adressoit specialement à eux. Maintenant donc les voila banniz du royaume de Dieu et nous sommes entrez en leur place". CO38,407 (comm. Jer. 23:5 "ludaei, qui Deo propinqui et foederati erant, adeoque legitimi vitae aeternae haeredes, perditi tamen dicuntur, donec salutem in Christo recuperent."

27 CO 49,189, comm. Rom. 9:26 "Quando enim iram Dei ita ludaei peccatis suis provocarunt, ut repudiari ab ipso mereantur, nulla salutis spes superest, nisi ad Christum se convertant."

28 CO 49,218, comm Rom. 11:11: "Hic merito negat, ludaeorum salutem esse deploratam, aut sic abiectos a Deo, ut nulla restitutio futura sit, vel prorsus exstinctum sit quod semel cum illis pepigit gratiae foedus: quandoquidem in gente semper manebat semen benedictionis ... natio tamen ipsa non concidit, ut necesse sit perditum esse vel a Deo alienum, qui ludaeus est."

29 Inst. IV,16,14. "Neque vero quantacunque contumacia cum Evangelio bellum gerere persistant, ideo tamen nobis sunt despiciendi: si reputamus, in promissonis gratiam, Dei benedictionem inter eos etiamnum residere: ut certe numquam inde prorsus abscessuram Apostolus testatur: quoniam sine poenitentia sunt dona et vocatio Dei" OS V,317/318. Cf. Jes. 14:2: CO 36,247: "Ad haec proprie veris et legitimis Abrahae filiis convenit hoc vaticinium ....". The Jews remain the first heirs!

30 Jansen (1981) stresses in a one-sided way the negative aspects of Calvin's view upon the Jews.

31 Inst. III,2,22 "Quemadmodum autem in illa ludaeorum reiectione supererant aliqui ex ipsis qui ab adoptionis foedere minime exciderant." OS IV,33. Cf. CO 49,175, comm. Rom. 9:6, "Si quis aliis verbis mavult, communis populi Israelitici electio non impedit quominus sibi deligat arcano suo consilio Deus quos visum est." 
blessing of God remains with Christians, they are not allowed to feel contempt for Jews. ${ }^{32}$ There, however, seems to be little hope for Israel as a people and no expectance of a future spiritual restoration of the Jewish nation as a whole. 33 Only a rest will be saved, namely the hidden seed of the election. ${ }^{34}$ Especially Calvin's commentary upon chapters 911 of the letter to the Romans is of great interest. He argues in these chapters that the covenant of grace which God has made with His people Israel has not been totally dissolved. But he seems not to go further than stating that as a result of the remaining election of Israel there will always be some individual Jews who will be saved in Christ.

In my opinion Calvin goes too far in spiritualising the promises of God's enduring covenant with Israel (see Van Campen, 1999:75). For him the role of the Jews as a nation is definitely outdated (Van Campen, 1988:122). The special place of the natural seed of Abraham has been an interim, a transient phase in the salutary plan of God until the Messiah will have come. Rightly Krüger (1985:36) comments that this is a position before the "Holocaust". Calvin could not have the perspectives we have after the murder upon six million Jews and after the return of the people of Israel to the land of their fathers!

Summarizing, we can say that, according to Calvin, the Kingdom of Christ is a spiritual Kingdom, and that we only by pilgrimage can reach the happiness of that Kingdom. The coming of the Kingdom is a process of growth in the spiritual lives of the believers and also in the numbers of them. The completion of this process will be seen on the day of the last

32 CO 49,172: “... quamvis illi increduli et foedifragi essent, non tamen eorum perfidia exinanitam esse Dei fidem. Non modo quia residuum sibi aliquid semen ex tota multitudine servavit, sed quia haereditario iure nomen ecclesiae adhuc penes ipsos manebat"; 171 "... cuius adhuc vigebat electio in radice, quamvis rami exaruissent".

33 CO 23,237, comm. Gen. 17:7: "Tunc populus Israel quasi grex Dei in proprium eius ovile receptus est; et reliquae gentes, tanquam ferae bestiae, per montes et sylvas aut deserta errarunt ... tandem foras eiecti sunt ludaei, nisis quod penes eos manet occultum electionis semen, ut reliquiae salvae fiant." CO 49, 226, comm Rom. 11:26: "Multi accipiunt de populo iudaico, ac si Paulus diceret instaurandam adhuc in eo religionem ut prius: sed ego Israelis nomen ad totum Dei populum extendo, hoc sensu: quum gentes ingressae fuerint, simul et ludaei ex defectione se ad fidei obedientiam recipient; atque ita complebitur salus totius Israelis Dei, quem ex utrisque colligi oportet; sic tamen ut priorem locum ludaei obtineant, ceu in familia dei primogeniti. Et eodem modo ad Galatas cap. 6,16 Israelem Dei nuncupit ecclesiam ex ludaeis et gentibus pariter compositam, populum ita ex dissipatione collectum opponens carnalibus Abrahae filiis, qui ab eius fide disciverant."

34 Detmers (2001:267): "Calvins Lehre von der verborgenen Erwählung Gottes ... markierte den entscheidenden kritischen Vorbehalt gegenüber der These einer endgültigen Verwerfung der Nichtgläubigen und der traditionellerweise daraus abgeleiteten Repressionspraxis." 
judgment, which is at the same time the intrada of the perfection (cf. Tukker, 1975:286). 35

\section{Millenarian eschatology}

At this point, I need to turn to certain millenarian views as advocated by several Evangelical theologians (see p.e. Pentecost, 1964; LaHaye \& Jenkins, 2000; Lindsey, 1970). The subjects that John Calvin gave so little attention to are now fully in the centre of interest in debates on eschatology. In this regard one thinks of aspects like the following:

- The place and role of Israel in the plan of God (Rom. 9-11).

- The rapture of the Christian church according to 1 Thessalonians 4.

- The great tribulation.

- The Antichrist and Armageddon.

- The millennium (Rev. 20).

It seems to me that an open debate between orthodox Calvinists (like Hoekema, 1979) and representatives of these millenarian Evangelicals could be enriching and refreshing for the theological standpoints on both sides. A sympathetic attempt to open and facilitate this debate is given by W.J. Ouweneel (1991). Very important for the success and for a positive outcome of this debate is the affirmation of the common elements of faith on which both camps stand. When we accept one another fully as brethren and sisters in Christ, we will be eager to listen to one another and to learn from one another. This does not mean that it would be good to minimise the differences. The different approaches at stake here are essential. For example the different visions upon the future of Israel have a central place in the debate between Calvinists and millennialists.

Regarding this subject, we notice that several forms of millennialism concur with the teaching of Judaist apocalyptic literature that the Messiah will come as the Son of David, who will re-establish Israel after the flesh. In this view, the Messiah will reign on this earth as a king upon the literal throne of David. Old Testament prophecy concerning the messianic kingdom should be interpreted as referring to the physical, literal kingdom of Israel on earth. The dispersed of Israel will again be gathered in the Holy Land and the glory of the present Jerusalem will be

35 A good example and summary of this Calvinistic eschatological approach is to be found in article 37 of the Confessio Belgica. See Verboom (1999:301-327); Müller (1903: 248, 249). 
greater than ever before, while ideal conditions will prevail on earth. It is also advocated by some theologians that contingent upon this return of the kingdom of David will be the restoration of the temple and even of its services, such as the sacrifices, the keeping of the laws of Moses and all other things characteristic of the religion of Israel. Animal sacrifices will again be offered in the rebuilt temple, not as propitiatory offerings, but as memorial offerings, in remembrance of Christ's death for us.

In different ways, Millenarians give further and various details in their future scenarios. Yet, if one speaks of a premillenarian or dispensational project of the future, one often gets the impression that the Christian Church of the New Testament is only an interlude, a parenthesis. The main route, the highway so to say, of God through history, is His way with His people of Israel. The position is taken that God does not have one people, but actually two peoples, which will never be mixed up with each other and which will coexist in all eternity, namely:

- the first born son, the elected people of Israel;

- the Christian congregation, gathered from the goyim, the heathen peoples.

This way of thinking is not accepted by most Calvinists. In their opinion the Scriptures clearly teach that God has but one people and this will be one flock under the rule of one Shepherd (John 10:16). The Bible does not start with Genesis 12, the vocation of Abraham, but with Genesis 1, the creation of heaven and earth and of all mankind. In the Netherlands, bumpers on automobiles sometimes show the sticker "Israel = Israel". This means that every time when the word "Israel"' is used in the Old and the New Testament, it can only be interpreted as the literal, ethnic Israel, the offspring of Abraham after the flesh. It seems to me that this is a simplification of a very complex matter. It is clear, for instance in 1 Peter $2: 9$, that traditional epithets, qualifications of the people of Israel, are related and transferred to the Christian church, the "new Israel", where Jews and heathen in Christ have been united in one spiritual body. Such traditional Christian interpretations cannot be ignored.

It is my distinct worry, that especially the dispensational approach could lead to an underestimation of the New Testament in relation to the Old Testament and could seriously neglect the richness and fullness that is in Christ, our Lord. The hermeneutical rule of Augustine that what is hidden in the Old Testament, is open in the New Testament (Polman, 1955:97121), implies that the way in which Old Testament prophecies are explained in the New Testament must guide us when reading and interpreting other Old Testament passages dealing with the future. We must see the Old Testament through the eyes of the apostles. 
In this respect we have conceivably a point of friction between orthodox Calvinists and dispensationalists. Thus debate between them will have to concentrate on hermeneutical questions. Theologians can not be aware enough of the danger of pressing scriptural data into pre-fabricated models and schemes. We have always to remind ourselves that the scenarios of the future we think are accurately and conscientiously derived from Scriptures, may, none the less, never be identified with the infallible plan of God. It may indeed be a step too far to develop a scenario of the future. The Scriptures speak in a poetic way about the great future, circling around the mystery of the coming of the Lord. There is no blueprint of this plan for us in the Scriptures other than only the decisive revelation in Christ. In Him we see the fulfilling of the great and precious promises of God - and this fulfilment is raising in our hearts a well-founded expectation of what God is going to do in the future. This concentration on the coming Christ will unite all true Christian believers in their common prayer "Maranatha, Lord Jesus, come!"

Another danger of dispensational or premillenarian eschatology is, in my opinion, that this way of thinking could overemphasize the theologia gloriae, by which the cross of Christ no longer is regarded as crucial for Christian theology and life. Certainly one could object that in the sermons and songs of these co-believers the cross does have a place, even a prominent place. However, certain concepts on eschatology give us the impression that "the cross" is less important than the "resurrection" on Easter; as if the good news of the resurrection of Christ makes the cross an outdated reality. The life of the Christian is then seen, in the first place, as a life of triumph. The reborn Christian is actually living a new life full of power and strength. He succeeds and flourishes in the ways of the Lord. Some go as far as to say that the reborn Christian can subdue all sin and can live a life of victory. In this approach, we hear much about the free choice of man, the new powers and abilities of Christians and such "glories". In my opinion, it is this theological starting-point that lies behind the opinions that Christians will not experience the great tribulation.

\section{The ongoing debate}

A revitalisation of Calvinistic eschatology is necessary. Eschatology has not received enough room in the early Calvinistic confessional tradition. ${ }^{36}$

36 See Jacobs (1959:132) "Die späteren Bekenntnisschriften, mit Ausnahme des Heidelberger Katechismus, verlagern das eschatologische Gut in einen Schlussartikel oder verzichten überhaupt auf eine spezielle eschatologische Aussage - eine Allgemeinerscheinung in der geschichtlichen Entwicklung der reformierten Bekenntnisschriften aus der zweiten Hälfte der Reformationszeit einschliesslich der Konkordienformel." 
In the times of the Puritans and of the "Nadere Reformatie" in the Netherlands a new interest in eschatological issues has awakened. In our own time the ongoing debate of Calvinists with all kinds of Millenarians can prompt a needed revitalisation of eschatological awareness and reflection. Let me concede two important aspects, which call for attention in this connection.

In the first place, I welcome in the millenarian positions their affinity with the people of Israel, and their insistence upon the unique place, which this elected people has had and will have in God's plan of salvation with the world and with history. Agreed, we must avoid the great pitfall of what is called the theology of substitution. ${ }^{37}$ This theological approach holds that the Christian Church has replaced the people of Israel and that the Jews do not have any special position in our eschatological expectations. Consequently, it is held that in the eyes of God there is no difference whatsoever between the Jewish people and each and every other people in this world. Nowadays, Calvinist theologians increasingly disagree with this, since they are convinced that God's election of the Jewish people remains valid in all eternity (see for instance Graafland, 1978). His covenant cannot be broken (Romans 9-11). It is also not right to say that all the rich promises, which the Old Testament contains regarding the future of Israel, have been translated and transferred solely to the Christian Church. Calvinists are convinced that the promises of God have already become true in Christ, who is the true seed of Abraham and the true Israel. Nevertheless, we must leave room for the multiple fulfilment of Old Testament prophecy. Prophecies that have been historically and partially fulfilled in the history of Israel, then, have been principally and spiritually fulfilled in Christ, and his Kingdom will finally be totally and plenary fulfilled on the new earth. We acknowledge that these promises can also have a preliminary fulfilment in future history (cf. Paul, 1992). 38

If we indeed may assume, as I am inclined to do, that several Old Testament promises will have a literal fulfilment to Israel in future history, we must be careful again. Let us keep in mind the wise reservedness of

"Vervangingstheologie" in the Dutch language.

38 Cf. Payne (1980:107): "Ultimately, the most satisfactory method of interpretation appears to lie in a synthesis that combines, wherever possible, the belief in a literal future accomplishment with the conviction of its universal applicability to the spiritual people of God. One may thereby maintain both the reality of the coming kingdom of Israel upon earth and, at the same time, the confidence that its saved citizenry will consist of our NT church. The amillennialist who hesitates over the one and the dispensational premillennialist who hesitates over the other seem equally to be subject to criticism." 
Calvin. The Word of God cannot be handled like a weather forecast and the Bible is no puzzle-book. However, this awareness does not hamper the expectation that many prophecies in the near future will be proved to be true in the mysterious way God deals with Israel and with the Church.

This openness for the predictions of Scripture concerning Israel's conversion is, of course, not a new feature in Calvinistic theology. Previously, the successor of John Calvin in Geneva, Theodorus de Beza (1519-1605), accepted a modified Augustinian approach to eschatology by interpreting Romans 11:25 ff. as meaning the future conversion of the Jewish people to Christ. lain Murray (1971) has pointed out that the majority of the Puritans actually believed that a future period of worldwide blessing was at hand (see also Toon, 1970:6, 7). The more famous Puritan exponents of the modified Augustinian eschatology with more elaborated and strengthened optimistic aspects included Thomas Brightman, William Gouge, John Cotton and John Owen. Many of them also taught that there will be a restoration of Jews to their ancient homeland in the Near East, either after, or, at the same time as their conversion to Christ. Yet, these convictions did not have a dispensational or premillenarian basis, though. So they did not teach two appearances of Christ, one at the beginning of, and one at the close of the millennium, and they also did not believe in the occurrence of two resurrections, the first of the martyrs only and the second of all the dead. These Calvinists did not need to shift from their Christocentric paradigm when they accepted the future conversion of the people of the Jews (Van Campen, 2000:20-36; Van Elderen, 1992; Van den Berg, 1969 and 1970). Their original awareness of the remaining place and enduring election of Israel fitted into a true Calvinistic theological framework! A good example of this development can be found in the chapter, "Of the Church", in the Confession of the Independents, the Savoy Declaration of 1658, cap. $\mathrm{XXV}$ :

So according to this promise we expect that in the later days, Antichrist being destroyed, the Jews called, and the adversaries of the kingdom of his dear Son broken, the Churches of Christ being enlarged, and edified through a free and plentiful communication of light and grace, shall enjoy in this world a more quiet, peaceable and glorious condition than they have enjoyed (Murray, 1971:53; Müller, 1903:599).

Many Dutch theologians of the seventeenth century also firmly believed that the conversion of Israel would take place in the "last days" and that this event would give the church a new blaze of the Spirit (like for instance Herman Witsius). Nevertheless, at the same time "they feared that the extravagant opinions of the chiliasts might endanger the belief in 
the biblical truth of a future conversion of the Jewish people" (Van den Berg, 1970:149). Some theologians like Jean de Labadie, Pierre Jurieu and Petrus Serrarius went much further and expressed their expectation that the converted Jews would govern the earth under the personal reign of Christ (Op 't Hof, 1984). But even with them we certainly do not find the idea that God has two peoples instead of one people, one church from the beginning of the world until the last day (Heidelberg Catechism, Q. and A. 54; Müller, 1903:696). It was held that when in the future the Jewish people as a whole, or nationally, would accept Jesus Christ as their own Messiah, this would not lead to a new division of the Christian Church into a Jewish part and into a heathen part. In that one and only Christian Church, the ethnic Jews would then play an important role, numerically and by their spiritual influence. Undoubtedly, Jerusalem would again - as once in the beginning of church history - have a central position within worldwide Christianity. Just as the proclamation of the Gospel had its starting point in Jerusalem, so again, the blessings of the Gospel would return to Jerusalem in the last days. Jerusalem would become the spiritual centre of the world! It is crucial for the Calvinistic position to stress that the dividing wall of hostility, which has been broken down by the work of Christ, will never be erected again (Eph. 2:14, 15).

In my opinion, we can find in these theological developments within the orthodox Calvinistic tradition a good starting-point for a fruitful encounter with the premillenarian approaches. That encounter can revitalise the insights of the Puritans with regard to the future of Israel.

A second aspect of this revitalisation of Calvinistic eschatology by the encounter with representatives of millenarian thinking is the renewal of the conviction that the theologia crucis has to leave room for the reality of Easter, not only in the life of Christians personally, but also in the historical developments of this world. A Christian's life is not exclusively a life of suffering, wrestling and of bitter fighting. The communion with the sufferings of Christ accompanies the new life in the power of His resurrection. Romans 7 has always to be linked with Romans 8. Applying this vision upon history brings us to concur with the Dutch theologian Hendrikus Berkhof (1966) that world history stands not only in the token of Good Friday, but also in that of Easter. Repeatedly we see in history the dark and long shadows of the cross of Christ: tribulation, persecution, and all kinds of suffering, etcetera. Thus, Auschwitz can be seen as a shadow of Golgotha in history. At the same time, we see points of light, reminders of Easter, tokens of the victory of Christ in history. We may not only regard history as a huge wave of misery, or as an enduring storm and tribulation. By grace, there are also sunny days, moments and times when the clouds are driven away, and oases appear during the pilgrimage of the people of God. 
As Christians, we may hope that in the days to come, before the great day of the parousia of Christ, God will do wonders of grace and of spiritual revival in the history of this world. Appealing to the words of the apostle Paul in Romans 11, we may expect that there will be a conversion of the people of Israel - as a people - to their Messiah, Christ Jesus. Listening carefully to the testimony of Revelations 20, we may look forward to a near future in which not secularisation and paganism, but spiritual awakening and true godliness will set the tone in this world. Meanwhile, the ultimate hope of all Christians concentrates on the word of Christ: "Surely, I will come soon." This coming of the Lord will bring the new heaven and the new earth, on which righteousness finally will be at home.

\section{Bibliography}

$\mathrm{CO}=$ Corpus Reformatorum

Corpus Reformatorum (Calvini Opera: Ioannis Calvini Opera Quae Supersunt Omnia). Brunsvigae : Baum, Cunitz, Reuss. 1895 (1964). New York/London : Johnson Reprint Corporation. CO is CR 29-88.

CALVINUS, J. 1559. Institutio Christianae religionis, in libros quattuor nunc primim digesta, certisque distincta capitibus, ad aptissimam methodum; aucta etiam tam magna accessione ut propemodum opus novum haberi possit. O.S. III-IV. München : Christian Kaiser Verlag. 1963.

BALKE, W. 1973. Calvijn en de doperse radikalen. Amsterdam : Bolland.

BALKE, W. 1978. De toekomstverwachting in de tijd van de Reformatie, vooral bij Calvijn. (In Van der Graaf, J. \& Snoei, C., ed. Profetie of fantasie? Amersfoort : Echo. Ook in Balke, W. 1992. Omgang met de reformatoren. Kampen : Kok. p. 210-221.)

BERKHOF, H. 1966. Christus de zin der geschiedenis, Nijkerk : Callenbach.

BREMMER, R.H. 1943. Enkele karakteristieke trekken van Calvijns eschatologie. Gereformeerd Theologisch Tijdschrift, 44:65-96.

BRIENEN, T. 1983. Reformatie en Nadere Reformatie over de plaats van Israël in het heilshandelen van God. (In Den Boer, C., Van Campen, M. \& Van der Graaf, J., ed. Zicht op Israël, Israël in het licht van de Bijbel en in de traditie van de Reformatie. 's-Gravenhage : Boekencentrum. p. 111-120.)

BRUNNER, P. 1925. Vom Glauben bei Calvin. Tübingen : Mohr (Paul Siebeck).

DE BOER, Eric A. 1990. Hermeneutische Schlüssel zur alttestamentlichen Prophetie in Calvins Hesekielpredigten. (In Neuser, W.H., ed. Calvinus Sacrae Scripturae Professor: Calvin as a Confessor of Holy Scripture. Die Referate des Internationalen Kongresses für Calvinforschung, vom 20. bis 23. August 1990 in Grand Rapids. Grand Rapids, Mi. : Eerdmans. p. 199-208.)

DE BOER, Eric A. 1997. The book of Revelation in Calvin's Geneva. (In Neuser, W.H. et al., Calvin's books. Festschrift for Peter de Klerk. Heerenveen : Groen. p. 23-62.)

DE GREEF, W. 1984. Calvijn en het Oude Testament. Amsterdam : Bolland.

DE GREEF, W. 1997. The origin and development of the doctrine of the covenant. (In Neuser, W.H. et al. Calvin's books. Festschrift for Peter de Klerk. Heerenveen : Groen. p. 337-356.)

DE REUVER, A. 1978. Belofte, boete, ballingschap - drie thema's bij Calvijn. Dordrecht : J.P.v.d.Tol. 
DETMERS, Achim. 2001. Reformation und Judentum. Israel-Lehren und Einstellungen zum Judentum von Luther bis zum frühen Calvin. Serie Judentum und Christentum. Bd. 7. Stegemann, Ekkehard W.W. herausg. Stuttgart/Berlin/ Köln : Kohlhammer Verlag.

ELLWEIN, Eduard, 1953. Meditatio Coelestis Vitae in Calvins Exegese. Zum Verständnis der apostolischen Paränese. (In Wendland, H.D., red. Kosmos und Ekklesia. Festschrift für W. Stählin. Kassel : Standa. p. 93 -101.)

GRAAFLAND, C. 1978. Het vaste verbond, Israël en het Oude Testament bij Calvijn en het Gereformeerd Protestantisme. Amsterdam : Bolland.

GRAAFLAND, C. 1992 (I-II); 1994 (III-IV); 1996 (V-VI). Van Calvijn tot Comrie. Oorsprong en ontwikkeling van de leer van het verbond in het Gereformeerd Protestantisme. Zoetermeer : Boekencentrum.

GRIER, W.J. 1945. The momentous event. A discussion of Scripture teaching on the Second Advent. Belfast : Evangelical Bookshop. (1970, 1976. Edinburgh : The Banner of Truth Trust.)

HOEKEMA, A.A. 1979. The Bible and the future. Michigan : Eerdmans.

HOLWERDA, David Earl. 1976. Eschatology and history: a look at Calvin's eschatological vision. (In Holwerda, David E., ed. Exploring the heritage of John Calvin. Essays in honour of John H. Bratt. Grand Rapids (Mi.) : Eerdmans. p. 110-139.)

JACOBS, P. 1959. Theologie Reformierter Bekenntnisschriften in Grundzügen. Neukirchen : Neukirchener Verlag.

JANSEN, H. 1981. Christelijke theologie na Auschwitz, I. Theologische en kerkelijke wortels van het antisemitisme. 's-Gravenhage : Boekencentrum.

KRÜGER, Horst. 1985. Erben des Evangeliums. Calvin und die Juden, Kamper Cahiers. Kampen : Kok.

LAHAYE, Tim \& JENKINS, Jerry B. 2000. Are we living in the end times? WheatonIllinois : Tyndale House Publishers.

LINDSEY, Hal 1970. Late great planet earth. Michigan : Zondervan.

MEYER, W.E. 1966. Soteriologie, Eschatologie und Christologie in der Confessio Helvetica Posterior. Zwingliana, 12:391-409.

MÖLLER, F.P. 1998. The great endtime events (Eschatology). Words of light and life 7. Pretoria : Van Schaik Religious Books.

MÜLLER, E.F.K. 1903. Die Bekenntnisschriften der reformierten Kirche. Leipzig : Deichert.

MURRAY, lain 1971. The Puritan hope. A study in revival and the interpretation of prophecy. Edinburgh : The Banner of Truth Trust.

NIESEL, W. 1948. Bekenntnischriften und Kirchenordnungen der nach Gottes Wort reformierten Kirche. Zürich : Theologischer Verlag.

OP 'T HOF, W.J. 1984. De visie op de Joden in de Nadere Reformatie tijdens het eerste kwart van de zeventiende eeuw. Amsterdam : Bolland.

OS

see Calvinus, 1559

OUWENEEL, W.J. 1991. Israël en de kerk, oftewel: Eén of twee volken van God? Confrontatie van de verbondsleer en de bedelingenleer. Vaassen : Meinema.

PAUL, M.J. 1992. Terug naar de toekomst: de uitleg van de oudtestamentische profetieën over Israël. Theologia Reformata, XXV:278-298.

PAYNE, J.B. 1980. Encyclopedia of Biblical prophecy. Grand Rapids : Zondervan.

PENTECOST, J.D. 1964. Things to come: A study of Biblical eschatology. Grand Rapids : Zondervan. 
POLMAN, A.D.R. 1955. De theologie van Augustinus - Het Woord Gods bij Augustinus. Kampen : Kok.

QUISTORP, H. 1941. Die letzten Dinge im Zeugnis Calvins. Calvins Eschatologie. Gütersloh [diss. Halle] : Bertellsmann.

SCHOLL, Hans 1968. Der Dienst des Gebetes nach Johannes Calvin. Zürich/ Stuttgart : Zwingli Verlag.

SCHULZE, M. 1901. Meditatio futurae vitae, ihr Begriff und ihre beherrschende Stellung im System Calvins. Ein Beitrag zum Verständnis von dessen Institutio. Repr. Aalen, 1971. Leipzig : Scientia Verlag.

SPIJKERBOER, A.A. 1982. Een verpletterende boetepreek. Ter Herkenning, 10.

TORRANCE, T.F. 1956. Eschatology of hope: John Calvin. (In Kingdom and church. A study in the theology of the Reformation. Edinburgh : Oliver \& Boyd. p. 90164.)

TUKKER, C.A. 1975. Eschatologische momenten in zestiende-eeuwse belijdenisgeschriften. Theologia Reformata, XVIII(4):285-296.

VAN CAMPEN, M. 1988. Leven uit Gods beloften. Een centraal thema bij Johannes Calvijn. Kampen : Kok.

VAN CAMPEN, M. 1999. Het verbond bij Calvijn. (In Hagoort, Henk, ed. Het verbond van God met mensen. Heerenveen : Groen. p. 67-76.)

VAN CAMPEN, M. 2000. Het millennium gewogen. Het duizendjarig rijk in de visie van de Nadere Reformatie. Documentatieblad Nadere Reformatie, 24(1):20-36.

VAN DEN BERG, J. 1969. Joden en Christenen in Nederland gedurende de zeventiende eeuw. Kampen : Kok.

VAN DEN BERG, J. 1970. Eschatological expectations concerning the conversion of the Jews in the Netherlands during the seventeenth century. (In Toon, Peter, ed. Puritans, the millennium and the future of Israel - Puritan eschatology 1600 to 1660. Cambridge/London : Clarke. p. 137-153.)

VAN DEN BERG, M.A. 1996. Op weg naar het vaderland. De eschatologie bij Calvijn. Theologia Reformata, XXIX(4):265-287.

VAN DER KOOI, C. 1992. De spanning van het 'reeds' en het 'nog niet' bij Calvijn, Kuyper en Berkouwer. (In Brinkman, M.E., ed. 100 jaar theologie. Aspecten van een eeuw theologie in de Gereformeerde Kerken in Nederland (1892-1992). Kampen : Kok. p. 248-282.)

VAN DER LINDE, S. 1976. Calvijn en de geschapen werkelijkheid. (In Arendshorst, W.J. et al., red./samest. Opgang en voortgang der Reformatie. Een keuze uit lezingen en artikelen van Prof. dr. S. van der Linde. Amsterdam : Bolland. p. 5976.)

VAN ELDEREN, R.J. 1992. Toekomst voor Israël. Een theologisch-historisch onderzoek naar de visie op de bekering der Joden en de toekomst van Israël bij Engelse Protestanten in de periode 1547-1670 tegen de achtergrond van hun eschatologie. Kampen : Kok.

VAN WYK, J.H. John Calvin on the kingdom of God and eschatology. In die Skriflig, 35(1):191-213.

VELEMA, W.H. 1974. Ethiek en pelgrimage - Over de bijbelse vreemdelingschap. Ethisch kommentaar. Amsterdam : Bolland.

VERBOOM, W. 1999. Kostbaar belijden - de theologie van de Nederlandse Geloofsbelijdenis. Zoetermeer : Boekencentrum.

VISSER, A.J. 1963. Calvijn en de Joden. Miniaturen 2. Bijlage van het maandblad Kerk en Israël, 17. 


\section{Key concepts:}

Calvinistic theology

debate chiliasm - Calvinism

eschatology

future of Israel

Kernbegrippe:

Calvinistische theologie

debat chiliasme - Calvinisme

eschatologie

toekomst van Israël 
